\title{
Individual, school and natural environment influences on children with motor coordination problems: The Peruvian Health and Optimist Growth Study
}

Sara Pereira ( $\nabla$ sara.s.p@hotmail.com )

University of Porto

Alcibíades Bustamante

National University of Education Enrique Guzmán y Valle

Carla Santos

University of Porto

Donald Hedeker

University of Chicago

Go Tani

University of São Paulo

Rui Garganta

University of Porto

Olga Vasconcelos

University of Porto

Adam Baxter-Jones

University of Saskatchewan

Peter T. Katzmarzyk

Louisiana State University

José Maia

University of Porto

\section{Research Article}

Keywords: The Peruvian Health and Optimist Growth Study, motor coordination, environmental influences

Posted Date: April 26th, 2021

DOI: https://doi.org/10.21203/rs.3.rs-442712/v1

License: (c) (i) This work is licensed under a Creative Commons Attribution 4.0 International License.

Read Full License 
Version of Record: A version of this preprint was published at Scientific Reports on July 29th, 2021. See the published version at https://doi.org/10.1038/s41598-021-95075-7. 


\section{Abstract}

This study investigates the interplay between individual and natural environments, as well as the effects of school characteristics, on Peruvian children and adolescents' gross motor coordination (GMC) problems. The sample comprises 7401 participants (4121 girls) aged 6-14 years from three geographical regions: sea-level, Amazon and high-altitude. GMC categories (normal and with problems) were defined from the KörperkoordinationsTest für Kinder test battery. Stunting (height-for-age) and nutritional status (BMI-for-age) were obtained from WHO Growth Standards. Biological maturation was estimated, and physical fitness was measured. School context information was obtained from an objective audit. Logistic multilevel analysis was used. Results showed a high prevalence of GMC problems in Peruvian youth. Sex, age, geographical area of residence, biological maturation, nutritional status, stunting and physical fitness were important predictors of GMC problems. Moreover, there was an interaction between age, sex, and geographical area showing that girls, older subjects, and those from sea level regions were more likely to display GMC problems. The school context was less important in predicting GMC problems than the interplay between individual characteristics and the natural environment. The early identification as well as educational and pediatric care interventions are of utmost importance to reduce GMC problems among Peruvian children and adolescents.

\section{Introduction}

Gross motor coordination (GMC) is defined as the harmonious and economical interaction of musculoskeletal, nervous, and sensory systems that produce accurate and balanced motoric actions with minimal energy expenditure. ${ }^{1}$ Children with GMC problems experience considerable difficulties in performing motor tasks as well as challenges in their daily activities, school performance and social participation ${ }^{2-4}$. It is estimated that about $6 \%$ of children around the world have a GMC disorder ${ }^{5}$. Additionally, the prevalence of GMC problems ranges from 8.8 to $28 \%$ in children and adolescents ${ }^{6-8}$ and appears to be higher in countries with lower human development index ${ }^{9}$. Moreover, if these GMC problems are not resolved as early as possible, they can extend into adulthood, interfering with individual's professional laboring demands and daily activities.

It has been reported that GMC levels vary substantially among children and adolescents ${ }^{10-12}$, and that individual demographic and biological variables (e.g., age, sex, body mass index, physical fitness, gestational age, socioeconomic status, parental education, number of siblings, or birth order) and environmental characteristics (e.g., time spent outdoors in playing spaces, parents' physical activity and family interactions), seem to modulate them ${ }^{10-12}$. Yet, the role of environmental factors on explaining GMC variation is apparently unresolved. For example, a systematic review ${ }^{11}$ showed inconsistent results regarding the influence of socioeconomic status on GMC, which is similar to data from Niemistö, et al. ${ }^{13}$ of Finnish children from three geographical regions of the country scattered by residential density areas. Previous studies have rarely explored sets of putative covariates' influences in children chances of having 
a GMC problem, and have instead concentrated mostly on the associations with physical fitness and body composition ${ }^{8,14-16}$.

Natural environmental differences within a country may play an important role in shaping motor development and GMC among children and adolescents, and thus needs to be considered ${ }^{17}$. Peru is typically described in terms of three broad regions: the arid Coastal region in the west at sea level, the Sierra central region at high-altitude and the forested Amazonia in the east. Further, systematic differences in children and adolescents' lifestyles in these three regions are notorious because of their vastly different daily chores and subsistence activities ${ }^{18}$. All of these exert different influences on an individual's growth and development ${ }^{19}$. For example, de Chaves, et al. ${ }^{8}$ reported that Peruvian children and adolescents living at sea level or at high-altitude were more likely to suffer from GMC difficulties than those living in the Amazon region.

Children and adolescents spend a large portion of their waking hours at school ${ }^{20}$, and it is expected that school characteristics may also play an important role in resolving GMC problems. Indeed, Santos, et al.

21 reported that in Peruvian children, 31\% of the total variance in GMC (based on continuous raw scores) was explained by school characteristics. Also, interactions between the natural and built environments with individual characteristics in shaping GMC are expected to occur. To our knowledge, there is a lack of information on the interplay of GMC problems with individual characteristics (such as age, sex, biological maturation, physical fitness) and hence our understanding of their potential integrative influences on GMC problems is limited. We may come closer to this integrative understanding by using the multilevel statistical framework and probing the network of independent and interaction links between individual and environmental characteristics on GMC problems. Hence, the aim of this study is to address the following research questions: (1) are age, sex and geographical areas associated with children and adolescents' GMC problems during childhood and adolescence? (2) If yes, do age-by-sex, age-bygeographical area, and sex-by-geographical area interactions predict GMC problems? (3) If the two-way interactions are significant, do age-by-sex-geographical area predict GMC problems? (4) What are the relations of child-level characteristics on the likelihood of GMC problems? (5) Do school-level variables also relate to GMC problems?

\section{Results}

Descriptive statistics. Table 1 shows the child-level characteristics by GMC levels (normal and with problems). An increase in prevalence of GMC problems from 6-10 years to 11-14 years was observed $\left(X^{2}=216.035, p<0.05\right)$. Girls $(50.6 \%)$ had higher prevalence of $\mathrm{GMC}$ problems compared to boys $(18.3 \%$, $\left.\chi^{2}=824.33, p<0.05\right)$. Children and adolescents from sea-level $(49 \%)$ and high-altitude $(45.4 \%)$ had higher prevalence of GMC problems compared to their Amazonian peers (27.5\%). Moreover, children and adolescents with stunting had a higher prevalence than non-stunted children and adolescents $(40.0 \% \mathrm{vs}$ $\left.5.8 \%, \chi^{2}=7.150, p<0.05\right)$. A similar result was observed regarding weight status in which youth who were overweight and obese had a higher prevalence of GMC problems than their normal weight peers ( $40 \% \mathrm{vs}$ 
$\left.34.8 \%, \chi^{2}=17.875, p<0.05\right)$. Finally, those with high levels of physical fitness had a lower prevalence of GMC problems (22.7\%) when compared with those showing low (48.4\%) and medium (37.0\%) levels of fitness.

Table 1

Child-level characteristics by gross motor coordination

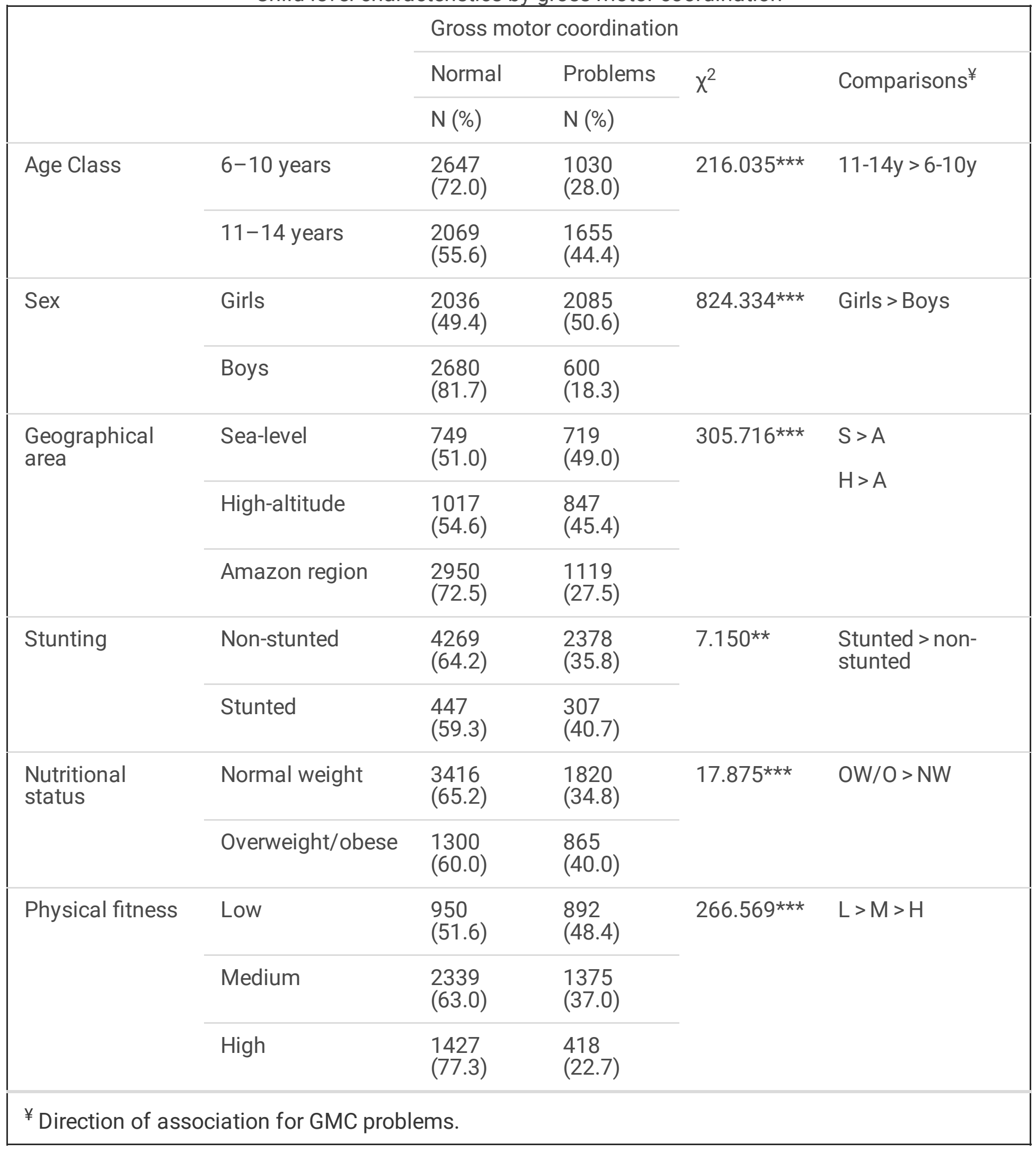


School-level characteristics are shown in Table 2. Eighty-three percent of schools were located in urban areas, with the number of students per school ranging from 96 to 1200 . Furthermore, $83.3 \%$ of schools had a playground without obstacles, and $33.3 \%$ had access to an indoor multi-sports complex. Forty-four percent of schools had neither policies nor practices for physical activity, whereas $16.7 \%$ had policies and $38.9 \%$ had practices for physical activity. In $55.6 \%$ of schools, physical education classes were more than 90 minutes in duration once a week, and children and adolescents active time during classes was, on average, $78 \mathrm{~min}$. Additionally, $77.8 \%$ of schools offered extracurricular activities, and $38.9 \%$ allowed students to use school infrastructures outside of school activities. 
Table 2

Descriptive statistics of the school-level characteristics [counts (n), frequencies (\%), means, standard deviations (SD) and ranges].

\begin{tabular}{|c|c|c|}
\hline & $\mathrm{n}$ & $\%$ \\
\hline \multicolumn{3}{|l|}{ School setting } \\
\hline Mixed & 3 & 16.7 \\
\hline Urban & 15 & 83.3 \\
\hline \multicolumn{3}{|l|}{ Policies and practices for physical activity } \\
\hline No & 8 & 44.4 \\
\hline Only Policies & 3 & 16.7 \\
\hline Only Practices & 7 & 38.7 \\
\hline \multicolumn{3}{|l|}{ Playground obstacles } \\
\hline Without obstacles & 15 & 83.3 \\
\hline With obstacles & 3 & 16.7 \\
\hline \multicolumn{3}{|l|}{ Indoor Multi-sports } \\
\hline No & 12 & 66.7 \\
\hline Yes & 6 & 33.3 \\
\hline \multicolumn{3}{|l|}{ Physical education classes duration } \\
\hline$\leq 90$ minutes & 8 & 44.4 \\
\hline$>90$ minutes & 10 & 55.6 \\
\hline \multicolumn{3}{|l|}{ Extracurricular activities } \\
\hline No & 4 & 22.2 \\
\hline \multirow[t]{2}{*}{ Yes } & 14 & 77.8 \\
\hline & Mean (SD) & Range \\
\hline Number of students per school & $453(263)$ & $96-1200$ \\
\hline Active time during physical education class & $78(16)$ & $50-110$ \\
\hline
\end{tabular}

Results of the multilevel analysis are presented in Table 3. The null model (data not shown) indicated that $15 \%$ of the total variance in GMC categories was explained by school-level characteristics, with the remaining $85 \%$ associated with distinct children and adolescents' traits. 
Question 1: are age, sex and geographical area associated with children and adolescents' chances of having GMC problems? Model 1 results show that older individuals were more likely to exhibit GMC problems than their younger peers $(\mathrm{OR}=1.686 ; 95 \% \mathrm{Cl}=1.454-1.956)$. Moreover, boys $(\mathrm{OR}=0.183 ; 95 \% \mathrm{Cl}$ $=0.161-0.209)$ and those living in the Amazon region $(\mathrm{OR}=0.366 ; 95 \% \mathrm{Cl}=0.230-0.581)$ were less likely to show GMC problems than girls and their sea-level peers, respectively.

Question 2: do age-by-sex, age-by-geographical area, and sex-by-geographical area interactions condition GMC problems? Model 2 was a better fit than Model $1\left(\chi^{2}=21.04,5 \mathrm{df}, \mathrm{p}<0.001\right)$ as indicated by a significant drop in the deviance statistic, and indicated that interaction effects were statistically significant. The age-by-sex interaction results revealed that although both boys and girls increased the probability of having GMC problems from 6-10 years through to 11-14 years, the increase with age was greatest in girls (see Fig. 1a). For the age-by-geographical area interaction, a significant effect $(p<0.05)$ was only observed between sea-level and amazon regions, indicating that sea-level youth have a greater chance of having GMC problems. Figure $1 \mathrm{~b}$ shows a lower probability for Amazonian subjects in both age classes $(6-10$ years $=23 \%$ and $11-14$ years $=36 \%)$ to demonstrate GMS problems when compared to sea-level peers $(6-10$ years $=45 \%$ and $11-14$ years $=53 \%)$ and high-altitude peers $(6-10$ years $=45 \%$ and $11-14$ years $=50 \%)$. However, it is important to note that the difference in rates of GMC problems for Amazonian subjects tend to be higher $(\sim 14 \%)$ than their counterparts from sea-level $(\sim 8 \%)$ and highaltitude $(\sim 5 \%)$ across age. Finally, there is a significant interaction in the sex-by-geographical area interaction (Fig. 1c), but only between sea-level and high-altitude Peruvian youth of both sexes.

Question 3: If the two-way interactions are significant, do age-by-sex-geographical area predict GMC problems? Model 3 was a better fit than Model $2\left(x^{2}=15.16,2 \mathrm{df}, p<0.001\right)$ indicating the importance of three-way interactions in both categories. Figure 2 shows that girls from the Amazon region had higher increases of the probability of having GMC problems between 6-10 years through to 11-14 years (23\%) than sea-level $(5 \%)$ and high-altitude (3\%) peers. Boys showed a different pattern: at $6-10$ years boys from sea-level and high-altitude had equal probability of having GMC problems (24\%) and higher probability than Amazon region (11\%). Additionally, boys from high-altitude and Amazon region from 610 years to $11-14$ years displayed residual increases in their probability of having GMC problems $(2 \%$ and $3 \%$, respectively), although boys from the sea-level presented higher increases in their probability $(19 \%)$.

Question 4: what are the relations of child-level characteristics on the likelihood of GMC problems? Model 4 was a better fit than Model $3\left(X^{2}=434.28,5 \mathrm{df}, \mathrm{p}<0.001\right)$, and showed that those ahead in their biological maturation $(\mathrm{OR}=1.820 ; 95 \% \mathrm{Cl}=1.651-2.005)$, stunted $(\mathrm{OR}=1.491 ; 95 \% \mathrm{Cl}=1.232-1.804)$, and being overweight or obese $(\mathrm{OR}=1.291 ; 95 \% \mathrm{Cl}=1.131-1.473)$ were more likely to have $\mathrm{GMC}$ problems. However, Peruvians with medium $(\mathrm{OR}=0.419 ; 95 \% \mathrm{Cl}=0.361-0.487)$ and higher $(\mathrm{OR}=0.150 ; 95 \% \mathrm{Cl}=$ 0.122-0.185) physical fitness levels had lower odds, i.e., were more protected of displaying GMC problems than their peers with low physical fitness levels. 
Question 5: do school level variables also relate to GMC problems? Finally, when school-level covariates were added (Model 5), no improvement in model fit was found relative to Model 4 ( $\chi^{2}=11.08$ with $9 \mathrm{df}, \mathrm{p}$ $>0.05)$. This suggests that, after accounting for individual characteristics and geographical location as well as their significant interactions, school-level characteristics did not significantly predict Peruvian children and adolescents' chances of having GMC problems. 
Table 3

Parameters estimates [odds ratios (OR) and 95\% confidence intervals] and variance components for gross motor coordination.

\begin{tabular}{|c|c|c|c|c|c|}
\hline & Model 1 & Model 2 & Model 3 & Model 4 & Model 5 \\
\hline Variables & $\begin{array}{l}\text { OR } \\
(95 \% \mathrm{Cl})\end{array}$ & $\begin{array}{l}\text { OR } \\
(95 \% \mathrm{Cl})\end{array}$ & OR $(95 \% \mathrm{Cl})$ & $\begin{array}{l}\text { OR } \\
(95 \% \mathrm{Cl})\end{array}$ & $\begin{array}{l}\mathrm{OR} \\
(95 \% \mathrm{Cl})\end{array}$ \\
\hline Age (11-14 years) & \multirow{2}{*}{$\begin{array}{l}1.686 \\
(1.454- \\
1.956)^{\star \star \star}\end{array}$} & \multirow{2}{*}{$\begin{array}{l}1.621 \\
(1.217- \\
2.159) \star \star\end{array}$} & \multirow{2}{*}{$\begin{array}{l}1.268 \\
(0.919- \\
1.749)\end{array}$} & \multirow{2}{*}{$\begin{array}{l}0.556 \\
(0.385- \\
0.801)^{\star \star}\end{array}$} & \multirow{2}{*}{$\begin{array}{l}0.582 \\
(0.406- \\
0.835)^{\star \star}\end{array}$} \\
\hline Sex (boys) & & & & & \\
\hline $\begin{array}{l}\text { Geographical area (high- } \\
\text { altitude) }\end{array}$ & $\begin{array}{l}0.183 \\
(0.161- \\
0.209)^{\star \star \star}\end{array}$ & $\begin{array}{l}0.338 \\
(0.198- \\
0.578)^{\star \star \star}\end{array}$ & $\begin{array}{l}0.221 \\
(0.119- \\
0.409)^{\star \star \star}\end{array}$ & $\begin{array}{l}0.126 \\
(0.064- \\
0.247)^{\star \star \star}\end{array}$ & $\begin{array}{l}0.077 \\
(0.037- \\
0.160)^{\star \star \star}\end{array}$ \\
\hline $\begin{array}{l}\text { Geographical area (amazon } \\
\text { region) }\end{array}$ & \multirow{2}{*}{$\begin{array}{l}0.904 \\
(0.554- \\
1.476)\end{array}$} & \multirow{2}{*}{$\begin{array}{l}1.263 \\
(0.709- \\
2.246)\end{array}$} & \multirow{2}{*}{$\begin{array}{l}1.239 \\
(0.669- \\
2.293)\end{array}$} & \multirow{2}{*}{$\begin{array}{l}1.514 \\
(0.740- \\
3.098)\end{array}$} & \multirow{2}{*}{$\begin{array}{l}1.505 \\
(0.369- \\
6.148)\end{array}$} \\
\hline Interactions (two-way) & & & & & \\
\hline Age-by-sex & \multirow{3}{*}{$\begin{array}{l}0.366 \\
(0.230- \\
0.581)^{\star \star \star}\end{array}$} & \multirow{2}{*}{$\begin{array}{l}0.360 \\
(0.212- \\
0.614)^{\star}\end{array}$} & \multirow{2}{*}{$\begin{array}{l}0.319 \\
(0.181- \\
0.561)^{\star \star \star}\end{array}$} & \multirow{2}{*}{$\begin{array}{l}0.425 \\
(0.220- \\
0.821)^{\star}\end{array}$} & \multirow{2}{*}{$\begin{array}{l}0.711 \\
(0.279- \\
1.811)\end{array}$} \\
\hline $\begin{array}{l}\text { Age-by-geographical area (11- } \\
14 \text { years/high-altitude) }\end{array}$ & & & & & \\
\hline $\begin{array}{l}\text { Age-by-geographical area (11- } \\
14 \text { years/amazon-region) }\end{array}$ & & $\begin{array}{l}0.722 \\
(0.564- \\
0.925)^{\star}\end{array}$ & $\begin{array}{l}1.918 \\
(1.008- \\
3.651)^{\star}\end{array}$ & $\begin{array}{l}0.872 \\
(0.438- \\
1.737)\end{array}$ & $\begin{array}{l}0.703 \\
(0.361- \\
1.367)\end{array}$ \\
\hline \multicolumn{2}{|l|}{$\begin{array}{l}\text { Sex-by-geographical area } \\
\text { (male/high-altitude) }\end{array}$} & $\begin{array}{l}0.886 \\
(0.591- \\
1.330)\end{array}$ & $\begin{array}{l}1.057 \\
(0.662- \\
1.690)\end{array}$ & $\begin{array}{l}0.854 \\
(0.520- \\
1.403)\end{array}$ & $\begin{array}{l}0.825 \\
(0.496- \\
1.372)\end{array}$ \\
\hline \multicolumn{2}{|l|}{$\begin{array}{l}\text { Sex-by-geographical area } \\
\text { (male/amazon region) }\end{array}$} & \multirow{2}{*}{$\begin{array}{l}1.450 \\
(1.019- \\
2.063)^{\star}\end{array}$} & \multirow{2}{*}{$\begin{array}{l}2.131(1.420- \\
3.197)^{\star \star \star}\end{array}$} & \multirow{2}{*}{$\begin{array}{l}2.428 \\
(1.570- \\
3.756)^{\star \star \star}\end{array}$} & \multirow{2}{*}{$\begin{array}{l}2.406 \\
(1.575- \\
3.674)^{\star \star \star}\end{array}$} \\
\hline \multicolumn{2}{|l|}{ Interactions (three-way) } & & & & \\
\hline $\begin{array}{l}\text { Age-by-sex-by-geographical } \\
\text { area ( } 11-14 y / \text { male/high- } \\
\text { altitude) }\end{array}$ & & $\begin{array}{l}0.560 \\
(0.319- \\
0.984)^{\star}\end{array}$ & $\begin{array}{l}0.786 \\
(0.395- \\
1.565)\end{array}$ & $\begin{array}{l}0.578 \\
(0.275- \\
1.212)\end{array}$ & $\begin{array}{l}0.947 \\
(0.427- \\
2.100)\end{array}$ \\
\hline $\begin{array}{l}\text { Age-by-sex-by-geographical } \\
\text { area ( } 11-14 y / \text { male/amazon } \\
\text { region) }\end{array}$ & & $\begin{array}{l}0.673 \\
(0.387- \\
1.170)\end{array}$ & $\begin{array}{l}1.252 \\
(0.395- \\
1.565)\end{array}$ & $\begin{array}{l}1.120 \\
(0.550- \\
2.282)\end{array}$ & $\begin{array}{l}1.838 \\
(0.848- \\
3.980)\end{array}$ \\
\hline $\begin{array}{l}\text { Other child-level } \\
\text { characteristics }\end{array}$ & & & $\begin{array}{l}0.439 \\
(0.205- \\
0.944)^{\star}\end{array}$ & $\begin{array}{l}0.512 \\
(0.229- \\
1.142)\end{array}$ & $\begin{array}{l}0.633 \\
(0.289- \\
1.386)\end{array}$ \\
\hline Maturity offset & & & 0.247 & & \\
\hline Stunting (yes) & & & $0.514)^{\star \star \star}$ & $\begin{array}{l}(0.124- \\
0.581)^{\star \star}\end{array}$ & $\begin{array}{l}(0.154- \\
0.687)^{\star \star}\end{array}$ \\
\hline $\begin{array}{l}\text { Body mass index } \\
\text { (overweight/obese) }\end{array}$ & & & & & \\
\hline 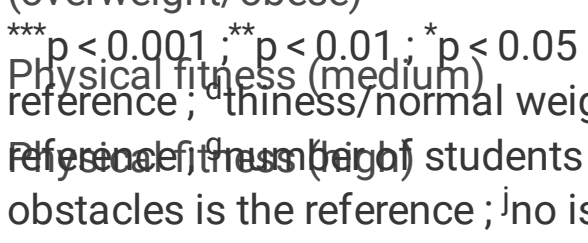 & vided by 1 & Ce, HIIIa & . & ; cgirls are & $\begin{array}{l}\text { is the } \\
\text { ithout }\end{array}$ \\
\hline
\end{tabular}




\begin{tabular}{|c|c|c|c|c|c|}
\hline School-level characteristics & Model 1 & Model 2 & Model 3 & Model 4 & Model 5 \\
\hline $\begin{array}{l}\text { School setting (urban) } \\
\text { Number of students } g\end{array}$ & & & & $\begin{array}{l}1.820 \\
(1.651- \\
2.005) \star \star \star\end{array}$ & $\begin{array}{l}1.823 \\
(1.652- \\
2.011)^{\star \star \star}\end{array}$ \\
\hline $\begin{array}{l}\text { Policies or practices for } \\
\text { physical activity (only policies) } \\
\text { h }\end{array}$ & & & & $\begin{array}{l}1.491 \\
(1.232- \\
1.804)^{\star \star \star}\end{array}$ & $\begin{array}{l}1.484 \\
(1.227- \\
1.795)^{\star \star \star}\end{array}$ \\
\hline $\begin{array}{l}\text { Policies or practices for } \\
\text { physical activity (only } \\
\text { practices) }\end{array}$ & & & & $\begin{array}{l}1.291 \\
(1.131- \\
1.473)^{\star \star \star}\end{array}$ & $\begin{array}{l}1.284 \\
(1.125- \\
1.465)^{\star \star \star}\end{array}$ \\
\hline $\begin{array}{l}\text { Playground obstacles (with } \\
\text { obstacles) }\end{array}$ & & & & $\begin{array}{l}0.419 \\
(0.361- \\
0.487)^{\star \star \star}\end{array}$ & $\begin{array}{l}0.419 \\
(0.360- \\
0.486)^{\star \star \star}\end{array}$ \\
\hline Indoor Multisports (yes) ${ }^{j}$ & & & & \multirow{11}{*}{$\begin{array}{l}0.150 \\
(0.122- \\
0.185)^{\star \star \star}\end{array}$} & \multirow{2}{*}{$\begin{array}{l}0.150 \\
(0.122- \\
0.184)^{\star \star \star}\end{array}$} \\
\hline Physical education classes & & & & & \\
\hline duration ( $\geq 90$ minutes) & & & & & \multirow{2}{*}{$\begin{array}{l}1.030 \\
(0.487- \\
2.178)\end{array}$} \\
\hline $\begin{array}{l}\text { Active time during physical } \\
\text { education classes }\end{array}$ & & & & & \\
\hline \multirow[t]{7}{*}{ Extracurricular activities (yes) ${ }^{\mathrm{j}}$} & & & & & $\begin{array}{l}0.999 \\
(0.998- \\
1.000)\end{array}$ \\
\hline & & & & & $\begin{array}{l}3.197 \\
(1.014- \\
10.080) \star\end{array}$ \\
\hline & & & & & $\begin{array}{l}0.948 \\
(0.504- \\
1.783)\end{array}$ \\
\hline & & & & & $\begin{array}{l}1.597 \\
(0.881- \\
2.897)\end{array}$ \\
\hline & & & & & $\begin{array}{l}1.551 \\
(0.730- \\
3.296)\end{array}$ \\
\hline & & & & & $\begin{array}{l}0.979 \\
(0.586- \\
1.638)\end{array}$ \\
\hline & & & & & $\begin{array}{l}1.010 \\
(0.992- \\
1.027)\end{array}$ \\
\hline \multicolumn{6}{|c|}{ 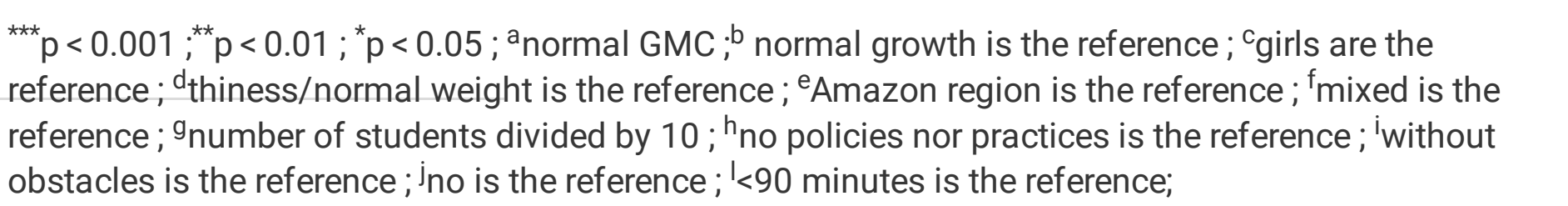 } \\
\hline
\end{tabular}




\begin{tabular}{|c|c|c|c|c|c|}
\hline & Model 1 & Model 2 & Model 3 & Model 4 & Model 5 \\
\hline & & & & & $\begin{array}{l}0.525 \\
(0.279- \\
0.987)^{\star}\end{array}$ \\
\hline Deviance & 8210.68 & 8189.64 & 8174.48 & 7740.20 & 7729.12 \\
\hline Number of parameters & 6 & 11 & 13 & 18 & 27 \\
\hline $\begin{array}{l}\Delta \text { in Deviance from previous } \\
\text { model ( } \Delta \text { in number of } \\
\text { parameters) }\end{array}$ & $\begin{array}{l}775.15 \\
(4)^{\star \star \star}\end{array}$ & $\begin{array}{l}21.04 \\
(5)^{\star \star \star}\end{array}$ & $15.16(2)^{\star \star \star}$ & $\begin{array}{l}434.28 \\
(5)^{\star \star \star}\end{array}$ & $11.08(9)$ \\
\hline \multicolumn{6}{|c|}{$\begin{array}{l}{ }^{* *} p<0.001 ;{ }^{* *} p<0.01 ;{ }^{*} p<0.05 ;{ }^{a} \text { normal GMC } ;{ }^{b} \text { normal growth is the reference } ;{ }^{c} \text { girls are the } \\
\text { reference } ;{ }^{d} \text { thiness } / \text { normal weight is the reference; }{ }^{e} \text { Amazon region is the reference; }{ }^{f} \text { mixed is the } \\
\text { reference } ;{ }^{g} \text { number of students divided by } 10 ;{ }^{h} \text { no policies nor practices is the reference } ;{ }^{i} \text { without } \\
\text { obstacles is the reference } ;{ }^{j} \text { no is the reference } ;{ }^{l}<90 \text { minutes is the reference; }\end{array}$} \\
\hline
\end{tabular}

\section{Discussion}

There is apparently no doubt that identifying children with GMC problems as well as their putative covariates is by itself a commendable effort given their implications for education and pediatric care ${ }^{22}$. We believe that the uniqueness of the present study is in the examination of the interactions between individuals and their environmental characteristics in explaining the presence of GMC problems. This is of chief importance for children living in developing countries such as Peru, and can be extended to other South-American children living in regions marked by geographical, cultural, and socioeconomic differences.

An important finding of this study is that the main fraction of GMC categories' variance (85\%) was explained by Peruvians' individual characteristics, which is similar to a report of Portuguese children ${ }^{23}$. Also, consistent with previous results, Peruvian girls are more likely to display GMC problems than boys ${ }^{8,21}$. This sex difference in GMC suggests a complex interplay between biological and cultural factors, which are probably linked to differences in sport participation, daily chores and distinct physical activities chosen by girls compared to boys. For example, Peruvian girls tend to spend their time after school in home activities (e.g., cleaning, cooking, etc.) whereas boys spend their time in sports' participation as well as in other varied physical activities.

We showed that older Peruvians were more likely to have GMC problems, which is a similar finding to Flemish children aged 5-12 years ${ }^{24}$. One plausible explanation for such results may be linked to differences in the timing and tempo of the growth spurt. This growth period is marked by an asynchrony in the growth of different parts of the body 25,26 that can adversely affect motor control, a phenomenon termed "clumsiness" or "adolescent awkwardness" 27 . For example, Bisi and Stagni ${ }^{28}$ in an experimental 
study compared the gait performance of growing (height increase $>3 \mathrm{~cm}$ in 3 months) and not growing (height increase $<1 \mathrm{~cm}$ in 3 months) male adolescents during a walking task and showed that the growth spurt influenced gait variability, smoothness and regularity. Additionally, whereas some children may perform some motor tasks awkwardly, others who grow steadily may be able to cope with their physical growth changes and thus maintain smoothness and regularity in some motor tasks. This was previously reported in Flemish male soccer players ${ }^{29}$ as well as in Belgium boys ${ }^{30}$. Indeed, these authors showed a temporary decline in performance during the growth spurt. Nevertheless, more longitudinal studies are needed to better understand the potential associated mechanisms ${ }^{31}$ as well as differences between boys and girls ${ }^{32}$.

The main challenge of the present study was to investigate how geographical areas interacted with individual-level characteristics (age and sex) to predict GMC problems. Based on a three-way interaction between age, sex, and geographical area we showed that older girls living at sea level are more likely to display GMC problems, whilst the youngest boys from the Amazonian region were less likely to have GMC problems. These results urge us to identify differences between these three regions that may have contributed to different probabilities of developing GMC problems, especially between the sea level and the Amazon regions. One possible explanation is associated with differences between these three regions in their natural, sociodemographic, health care and cultural characteristics (see Table 4 for more detailed information) that may influence lifestyle behaviors and routine activities. For example, the sea-level region has a higher human developmental index, high income and consequently better urban development and higher population density, where children tend to adopt certain lifestyle behaviors and other daily routine activities closer to youth from developed countries i.e., more sedentary activities and lower levels of physical activity. In fact, Sharma, et al. ${ }^{33}$ showed that $78 \%$ of Peruvian adolescents living at sea-level do not meet the WHO recommendations for moderate-to-vigorous physical activity. On the other hand, children and adolescents from the Amazon region tend to live in cities with less population density but larger areas. Peru's sea-level region represents $11 \%$ of the total area of the country but it is occupied by $65 \%$ of the total population, while the Amazon region represents $60 \%$ of the total area but only $5 \%$ of the total population reside in this region (approximately 1.6 million) ${ }^{34}$. Moreover, most families in the Amazon region are dependent on agricultural production and children tend to help their parents with these activities, especially during the weekend. The time spent in agriculture may provide children with rich opportunities to play freely in natural environments that increases their physical activity and improves their GMC.

Finally, when considering main effects of other individual characteristics, our results are consistent with previous research; biological maturation (favoring those less advanced), nutritional status (favoring normal weight), stunting (favoring non-stunted) and those more physically fit were less likely to have higher GMC problems ${ }^{10,21}$. These results are important pointers regarding their adverse or protective effects on the development of GMC problems. More specifically, nutritional status and stunting are risk factors while physical fitness is a protective factor in showing GMC problems. Moreover, these findings 
are concordant not only with other Peruvian studies ${ }^{8,21}$ but also with data from Portuguese ${ }^{11}$ and Flemish ${ }^{24,35}$ children and adolescents.

There is no doubt that schools are important when considering optimum physical growth, fundamental motor skills as well as GMC development ${ }^{1}$. Our findings showed that $15 \%$ of the total variance in GMC categories is accounted for by the school contexts. However, in the final model (model 5) when we added school characteristics after adjusting for individual characteristics, natural environments as well as their interaction, this model did not fit the data better than the previous one (model 4). This result most probably suggests that individual characteristics and natural environments seem to play more important roles than school characteristics to predict GMC problems in these Peruvian children and adolescents. This apparently reinforces our previous suggestion about the differences between regions being highly important in explaining differences between children and adolescents with GMC problems. This reiterates their impact on population lifestyles and consequently in children and adolescents GMC. However, these results highlight the importance for more research to tease out differences between countries and regions as well as contrasting high-income versus low-income countries.

This study is not without limitations. Firstly, the cross-sectional design does not allow any causal interpretation into the dynamics of individual and environmental complex relationships on changes in GMC problems. Secondly, we do not have information on other behaviors that can influence the links between stunting and GMC problems such as lifestyle behaviors (e.g., physical activity). Yet, given the sample size and the age range, this would be a daunting task and most probably an "impossible mission". Thirdly, we do not have information about the manifold aspects of home environments that may interact with individual characteristics and their development, which, in turn, may have a protective or negative effect on GMC disorders.

In conclusion, we showed a high prevalence of GMC problems in Peruvian children and adolescents which is more pronounced in girls, those aged 11-14 years and those living in the sea-level region. Further, these findings highlight the importance of individual and environmental characteristics influencing GMC problems, and this has key implications for physical education teachers to promote adequate levels of GMC development, as well as for pediatric care within local health-systems. Altogether, these results revealed the need to offer distinct physical education programs according to regions (i.e., sea level, high-altitude and amazon region) to accommodate their very dissimilar characteristics. Further, early identification of overweight/obesity status, stunting and physical fitness levels aligned with biological maturation may also help to implement precise intervention programs tailored to children and adolescents' characteristics. If subjects differ in some characteristics that condition their GMC unfolding, then there is a need to develop suitable pediatric care to foster and enhance their healthy growth and proper motor development.

\section{Methods}


Participants and geographical area of residence. Participants in the current study were drawn from "The Peruvian Health and Optimist Growth Study", which was conducted between November 2009 and July 2010. This study investigated the relationships between physical growth, motor development and health in Peruvian children and adolescents and their families ${ }^{36}$. Participants were recruited from 18 randomly chosen schools from the 78 schools in these three regions, and the original sample consisted of 10,424 boys and girls 6-17 years of age. Complete data were obtained from 7401 participants ( 4121 girls; 3280 boys 6 to 14 years old) - the age range of the GMC test battery is from 5 to 14.99 years.

Given the country's heterogeneity in geography, participants came from three distinct regions: sea-level, Amazon region and high-altitude. Barranco was the chosen city at sea-level in the Lima region. The cities of La Merced and San Ramon in the Chanchamayo district represented the Amazon region, and the Junín district was used to represent the high-altitude location. Participants included in the present study were natives of their respective regions (non-immigrants). Information with regards to birthplace and current place of residence was collected from individual's identity cards. Table 4 shows the distinct characteristics of these geographical locations, based on information provided by National Institute of Statistics and Informatics (INEI) ${ }^{37}$, city-halls ${ }^{38-40}$ and the digital platform of the Ministry for the Environment ${ }^{41}$.

Written informed consent was obtained from legal guardians, and the project was approved by the local school and political authorities, as well as by the Ethics Committee of the National University of Education Enrique Guzmán y Valle (UNE EGyV). All methods were performed in accordance with the relevant guidelines and regulations. Moreover, the study was performed in accordance with the ethical standards established in the Declaration of Helsinki 
Table 4

Natural, socioeconomic, demographic, health care and cultural features of the three regions

Sea-level

(Barranco)
Amazon region

(Chanchamayo)

High-Altitude (Junín)

Natural characteristics

Altitude (m)

58

751

4107

Precipitation, and

temperature (average)

Humidity

Arid; semi-

warm $\left(18^{\circ} \mathrm{C}\right)$

Humid

Rainy; warm

$\left(24^{\circ} \mathrm{C}\right)$

Rainy; cold

$\left(12^{\circ} \mathrm{C}\right)$

Very humid

Humid

\section{Socioeconomic characteristics}

Human Development index

0.72

0.52

0.44

Per capita family income

1440.6

785.1

512.7

Primary production

Trade/Tourism

Agriculture/Tourism

Stockbreeding/Agriculture

Demographic characteristics

8.564.867

411.011

1.272 .890

Population (total)

236.6

10.2

27.7

Population density

(people $/ \mathrm{km}^{2}$ )

Basic access to health care
Health center
Public hospital
Private clinic
Hospital campaigns and
tracking at school
Infrastructure for physical
activity and sports available

Parks

Yes

Yes

Yes

Playground

Yes

Yes

Yes

Pool

Yes

Yes

Yes

Multisport indoor

Yes

Yes

Yes

Multisport outdoor

No

Yes

Yes

Gymnastics complex

No

No

No 
Anthropometry. Body measurements were made according to standardized protocols [28]. Height and sitting height were measured using a portable stadiometer (Sanny, Model ES-2060) with the subject's head positioned in the Frankfurt plane, to the nearest $0.1 \mathrm{~cm}$. Body mass was measured to the nearest $0.1 \mathrm{~kg}$ using a digital scale (Pesacon, Model IP68). Technical error of measurement (intra-observer error) was $0.2 \mathrm{~cm}$ for height, $0.1 \mathrm{~cm}$ for sitting height, and $0.1 \mathrm{~kg}$ for body mass. BMI was calculated by dividing weight $(\mathrm{kg})$ by height squared $\left(\mathrm{m}^{2}\right)$.

Stunting and nutritional status. Stunting (height-for-age) and nutritional status (BMI-for-age) were predicted using age- and sex-specific WHO Child Growth Standards ${ }^{42,43}$. Two stunting groups were created: normal growth [height-for-age Z score $\geq-2$ standard deviation (SD)], and stunted growth (heightfor-age $Z$ score $<-2$ SD). Normal growth was used as the reference category in the models. Three nutritional status groups were created: thinness (BMI-for-age <-2 SD), normal weight (BMI-for-age between $\geq-2$ SD to $\leq 1 \mathrm{SD}$ ), and overweight/obese (BMI-for-age $>1 \mathrm{SD}$ ). However, given that only 40 subjects were classified with thinness ( $0.5 \%$ of the sample, representing 25 females and 15 males, 2 from sea-level, 15 from high-altitude and 23 from Amazon region), in the final models only normal weight and overweight/obese groups were considered and a thinness/normal weight grouping was used as the reference category.

Biological maturation. Biological maturation was assessed using a measure of somatic maturity predicted from anthropometrics to calculate a maturity offset value ${ }^{44}$. Maturity offset (years from peak height velocity) is an estimated temporal distance and is expressed in decimal years. Age at peak height velocity (PHV) is calculated as chronological age at assessment minus maturity offset. A positive (+) maturity offset indicates the number of years the participant is beyond attainment of PHV, whereas a negative (-) maturity offset represents the number of years the participant is before attaining PHV. This method has been widely used in children and adolescents ${ }^{45-47}$ and was previously used in other Peruvian studies ${ }^{19,48}$.

Physical fitness. Physical fitness was assessed using four tests: handgrip strength (static muscle strength component); standing long jump (explosive muscle strength component); shuttle-run (speed and agility component); and 12 min run (cardiorespiratory component). These tests are part of the EUROFIT test battery ${ }^{54}$ and the American Alliance for Health, Physical Education, Recreation and Dance (AAHPERD) test battery ${ }^{55}$. Reliability was estimated, and intraclass correlation values ranged from 0.79 in the shuttle-run test, to 0.85 in the handgrip test. Age-, and sex-standardized z-scores were computed for each test (the shuttle-run time was inverted), and then summed to obtain a total physical fitness z-score for each individual, as recommended ${ }^{56,57}$.

Gross motor coordination. Gross motor coordination was assessed using the Körperkoordination Test für Kinder battery (KTK), developed by Kiphard and Schilling ${ }^{49}$ for children and adolescents aged 5-14.99 years of age. This test battery has systematically been used in European ${ }^{50}$, African ${ }^{51}$, and SouthAmerica populations ${ }^{8,52}$. The KTK is explained in detail elsewhere (39). In brief, the battery contains four 
tests: walking backwards along a balance beam, hopping on one foot, jumping sideways, and moving sideways on boxes. A total KTK score is obtained from summing the scores obtained from each test. This unweighted sum of the scores, adjusted for age and sex, is named as the motor quotient (MQ), and has the following categories: (i) not possible ( $M Q<56$ ); (ii) severe motor disorder (MQ 56-70); (iii) moderate motor disorder (MQ 71-85); (iv) normal (MQ 86-115); (v) good (MQ 116-130); (vi) high (MQ $\geq 131$ ). For the present study, we only considered two broad categories: children and adolescents with normal GMC if $\mathrm{MQ}>85$, and children and adolescents with $\mathrm{GMC}$ problems if $\mathrm{MQ} \leq 85$ as recommended by Schilling ${ }^{53}$. In our statistical models, the normal GMC was used as the reference category. ANOVA-based intraclass correlation reliability estimates of children and adolescents GMC performance ranged from 0.78 in the moving sideways test to 0.92 in the walking backwards test.

School characteristics. Information concerning school characteristics was obtained via a questionnaire completed by a school administrator, assisted by a research team member. A modified, and locally adapted, version of the healthy eating and physical activity modules of the healthy school planner designed by the Joint Consortium for School Health was used ${ }^{58}$. The questionnaire included information from five domains: school size and characterization (number of children, number of teachers and school setting); healthy eating and physical activity policies (the existence, or not of policies and practices used by the school board); extracurricular activities (the existence and type of extracurricular activities available in the school); frequency and duration of physical education classes; school facilities (playground dimension and characterization, multi-sports roofed existence and dimension, number of structures and equipment available for physical education classes). For the present study, we only used information related to: school setting [mixed (reference category) or urban], number of students (continuous variable), policies and practices for physical activity [three categories: no policies nor practices (reference category); only policies; only practices], playground characteristics [with or without obstacles (reference category)], indoor multi-sport [existence or not (reference category)], physical education classes duration [two categories: $<90 \mathrm{~min}$ (reference category) and $\geq 90$ minutes], active time during physical education classes (continuous variables), extracurricular activities [two categories: no (reference category) and yes] and availability of school infrastructures outside of school activities [two categories: no (reference category) and yes].

Statistical analysis. Descriptive statistics are reported as means, standard deviations, and percentages as appropriate. Since the data were hierarchical in nature, i.e., participants nested within schools (two-levels), we used a multilevel logistic model ( $0=$ normal GMC; $1=\mathrm{GMC}$ problems) with a step-by-step modeling approach with increasing complexity: first, a null model with no predictors was estimated to calculate how much of the total variation in GMC categories was explained by the schools; second, five sequential models were built with varying complexity levels. Model 1 used age, sex and geographical area; model 2 built on model 1 and tested for two-way interactions: age-by-sex, age-by-geographical area and sex-bygeographical area; in model 3 a three-way interaction was added, namely: age-by-sex-by-geographical area; model 4 included other child-level characteristics such as stunting, BMI, maturity offset and physical fitness; model 5 included school-level characteristics. All model parameters were simultaneously 
estimated using maximum likelihood procedures, and when appropriate covariates were centered at their means as generally advocated ${ }^{59}$. Deviance (-2 log likelihood value) was used as a relative measure of model fit, with smaller values indicating a better fit to the data. When comparing nested models, we relied on differences in deviance, which follows a chi-square distribution with degrees of freedom equal to the difference in the number of estimated parameters from both models. Stata 14 was used in all analyses, and the significance level was set at $5 \%$.

\section{Declarations}

\section{Conflicts of Interest:}

The authors declare no conflict of interest.

\section{Author Contributions}

Statement: Conceptualization, S.P., C.S. and J.M.; formal analysis, S.P., D.H. and J.M.; investigation, A.B. and J.M.; data curation, A.B.; writing-original draft preparation, S.P., C.S., P.T.K and J.M.; writing-review and editing, S.P., C.S., P.T.K., J.M., D.H., G.T., R.G., O.V. and A.B.J.

\section{Acknowledgments:}

The authors thank all the schoolchildren of Barranco, Junín, San Ramon and La Merced who participated in this study. Also, we thank all the students and teachers of the UNE's Physical Education who contributed to the data collection

\section{References}

1 Gallahue, D. L. \& Ozmun, J. C. Understanding Motor Development: Infants, Children, Adolescents, Adults. 6th ed, (McGraw-Hill, 2006).

2 Cameron, C. E., Cottone, E. A., Murrah, W. M. \& Grissmer, D. W. How Are Motor Skills Linked to Children's School Performance and Academic Achievement? Child Dev. Perspect. 10, 93-98; 10.1111/cdep.12168 (2016).

3 Fernandes, V. R. et al. Motor Coordination Correlates with Academic Achievement and Cognitive Function in Children. Front Psychol. 7, 318; 10.3389/fpsyg.2016.00318 (2016).

4 Cummins, A., Piek, J. P. \& Dyck, M. J. Motor coordination, empathy, and social behaviour in schoolaged children. Dev Med Child Neurol. 47, 437-442; 10.1017/s001216220500085x (2005).

5 Zwicker, J. G., Missiuna, C., Harris, S. R. \& Boyd, L. A. Developmental coordination disorder: a review and update. Eur J Paediatr Neurol. 16, 573-581; 10.1016/j.ejpn.2012.05.005 (2012). 
6 Lingam, R., Hunt, L., Golding, J., Jongmans, M. \& Emond, A. Prevalence of developmental coordination disorder using the DSM-IV at 7 years of age: a UK population-based study. Pediatrics 123, e693-700; 10.1542/peds.2008-1770 (2009).

7 Veldman, S. L., Jones, R. A., Chandler, P., Robinson, L. E. \& Okely, A. D. Prevalence and risk factors of gross motor delay in pre-schoolers. J Paediatr Child Health. 56, 571-576; 10.1111/jpc.14684 (2020).

8 de Chaves, R. N. et al. Developmental and physical-fitness associations with gross motor coordination problems in Peruvian children. Res Dev Disabil. 53-54, 107-114; 10.1016/j.ridd.2016.01.003 (2016).

9 Tsiotra, G. D. et al. A Comparison of Developmental Coordination Disorder Prevalence Rates in Canadian and Greek Children. J Adolesc Health. 39, 125-127; 10.1016/j.jadohealth.2005.07.011 (2006).

10 Barnett, L. M. et al. Correlates of Gross Motor Competence in Children and Adolescents: A Systematic Review and Meta-Analysis. Sports Med. 46, 1663-1688 (2016).

11 Reyes, A. C. et al. Modelling the dynamics of children's gross motor coordination. J Sports Sci. 37, 2243-2252; 10.1080/02640414.2019.1626570 (2019).

12 Dos Santos, M. A. M. et al. Modeling children's development in gross motor coordination reveals key modifiable determinants. An allometric approach. Scand J Med Sci Sports. 28, 1594-1603; 10.1111/sms.13061 (2018).

13 Niemistö, D. et al. Environmental Correlates of Motor Competence in Children-The Skilled Kids Study. Int J Environ Res Public Health 16, 1989; 10.3390/ijerph16111989 (2019).

14 Schott, N., Alof, V., Hultsch, D. \& Meermann, D. Physical Fitness in Children With Developmental Coordination Disorder. Res Q Exerc Sport. 78, 438-450; 10.1080/02701367.2007.10599444 (2007).

15 Joshi, D. et al. Relationship between BMI, waist circumference, physical activity and probable developmental coordination disorder over time. Hum Mov Sci. 40, 237-247; 10.1016/j.humov.2014.12.011 (2015).

16 Hiraga, C. Y., Rocha, P. R. H., Ferracioli, M. d. C., Gama, D. T. \& Pellegrini, A. M. Physical fitness in children with probable developmental coordination disorder and normal body mass index. Rev. bras. cineantropom. desempenho hum. 16, 182-190 (2014).

17 Malina, R. M., Bouchard, C. \& Bar-Or, O. Growth, maturation and physical activity. (Human Kinetics, 2004).

18 Gallup, J. L., Gaviria, A. \& Lora, E. Is Geography Destiny?: Lessons from Latin America. . (Stanford University Press, 2003). 
19 Bustamante Valdivia, A., Maia, J. \& Nevill, A. Identifying the ideal body size and shape characteristics associated with children's physical performance tests in Peru. Scand J Med Sci Sports. 25, e155-165; 10.1111/sms.12231 (2015).

20 Donnelly, J. E. \& Lambourne, K. Classroom-based physical activity, cognition, and academic achievement. Prev Med. 52 Suppl 1, S36-42; 10.1016/j.ypmed.2011.01.021 (2011).

21 Santos, C. et al. A multilevel analysis of gross motor coordination of children and adolescents living at different altitudes: the Peruvian Health and Optimist Growth Study. Ann Hum Biol. 47, 355-364; 10.1080/03014460.2020.1742378 (2020).

22 Sugden, D. A. \& Henderson, S. E. Ecological intervention for children with movement difficulties. (Pearson Education, Ltd, 2007).

23 Chaves, R. et al. Effects of Individual and School-Level Characteristics on a Child's Gross Motor Coordination Development. Int J Environ Res Public Health 12, 8883-8896; doi:10.3390/ijerph120808883 (2015).

24 D'Hondt, E. et al. Gross motor coordination in relation to weight status and age in 5- to 12-year-old boys and girls: a cross-sectional study. Int J Pediatr Obes 6, e556-564; 10.3109/17477166.2010.500388 (2011).

25 Tanner, J. M. Sequence, Tempo, and Individual Variation in the Growth and Development of Boys and Girls Aged Twelve to Sixteen. Daedalus 100, 907-930 (1971).

26 Cole, T. J. Tanner's tempo of growth in adolescence: recent SITAR insights with the Harpenden Growth Study and ALSPAC. Ann Hum Biol. 47, 181-198; 10.1080/03014460.2020.1717615 (2020).

27 Visser, J., Geuze, R. H. \& Kalverboer, A. F. The relationship between physical growth, the level of activity and the development of motor skills in adolescence: Differences between children with DCD and controls. Hum. Mov. Sci. 17, 573-608; 10.1016/S0167-9457(98)00014-1 (1998).

28 Bisi, M. C. \& Stagni, R. Development of gait motor control: what happens after a sudden increase in height during adolescence? Biomed Eng Online. 15, 47; 10.1186/s12938-016-0159-0 (2016).

29 Philippaerts, R. M. et al. The relationship between peak height velocity and physical performance in youth soccer players. J Sports Sci. 24, 221-230; 10.1080/02640410500189371 (2006).

30 Beunen, G. et al. Adolescent Growth and Motor Performance. A Longitudinal Study in Belgian Boys. (Human Kinetics, 1988).

31 Quatman-Yates, C. C., Quatman, C. E., Meszaros, A. J., Paterno, M. V. \& Hewett, T. E. A systematic review of sensorimotor function during adolescence: a developmental stage of increased motor awkwardness? Br J Sports Med. 46, 649; 10.1136/bjsm.2010.079616 (2012). 
32 Davies, P. L. \& Rose, J. D. Motor skills of typically developing adolescents: awkwardness or improvement? Phys Occup Ther Pediatr. 20, 19-42 (2000).

33 Sharma, B., Chavez, R. C. \& Nam, E. W. Prevalence and correlates of insufficient physical activity in school adolescents in Peru. Rev Saude Publica. 52, 51; 10.11606/s1518-8787.2018052000202 (2018).

34 Stiperski, Z. \& Hruška, T. Social Changes in the Peruvian Amazon Due to Foreign Influence, Ecosystem and Biodiversity of Amazonia, Heimo Juhani Mikkola. IntechOpen, doi:10.5772/intechopen.94772 (2020).

35 D'Hondt, E. et al. A longitudinal analysis of gross motor coordination in overweight and obese children versus normal-weight peers. Int J Obes (Lond). 37, 61-67; 10.1038/ijo.2012.55 (2013).

36 Bustamente, A. Variabilidad del crecimiento somático y desempeño motor en escolares de Enseñanza Básica de la región central del Perú. Faculty of Sport, University of Porto, (2012).

37 INEI. Perfil sociodemográfico del Peru, Informe Nacional., <https://www.inei.gob.pe/media/MenuRecursivo/publicaciones_digitales/Est/Lib1539/index.html> (2018).

38 El Estado Peruano. Municipalidad Chanchamayo., $<$ http://www.munichanchamayo.gob.pe/turismo.php

39 El Estado Peruano. Municipalidad Junín., <https://www.munijunin.gob.pe/

40 El Estado Peruano. Municipalidad Barranco., <https://www.munibarranco.gob.pe/

41 SENAMHI. Peru Climate Map., <https://www.senamhi.gob.pe/

42 Butte, N. F., Garza, C. \& de Onis, M. Evaluation of the feasibility of international growth standards for school-aged children and adolescents. J Nutr. 137, 153-157; 10.1093/jn/137.1.153 (2007).

43 de Onis, M. \& Lobstein, T. Defining obesity risk status in the general childhood population: which cut-offs should we use? Int J Pediatr Obes. 5, 458-460; 10.3109/17477161003615583 (2010).

44 Mirwald, R. L., Baxter-Jones, A. D., Bailey, D. A. \& Beunen, G. P. An assessment of maturity from anthropometric measurements. Med Sci Sports Exerc. 34, 689-694; 10.1097/00005768-200204000-00020 (2002).

45 Pereira, S. et al. Profiling physical activity, diet, screen and sleep habits in Portuguese children. Nutrients 7, 4345-4362; 10.3390/nu7064345 (2015).

46 Morrissey, J. L., Janz, K. F., Letuchy, E. M., Francis, S. L. \& Levy, S. M. The effect of family and friend support on physical activity through adolescence: a longitudinal study. T Int J Behav Nutr Phys Act. 12,$103 ; 10.1186 / \mathrm{s} 12966-015-0265-6$ (2015). 
47 Costa, E. S. L., Fragoso, M. I. \& Teles, J. Physical Activity-Related Injury Profile in Children and Adolescents According to Their Age, Maturation, and Level of Sports Participation. Sports health 9, 118125, doi:10.1177/1941738116686964 (2017).

48 Santos, C. et al. Stunting and Physical Fitness. The Peruvian Health and Optimist Growth Study. Int J Environ Res Public Health 17, 3440, doi:10.3390/ijerph17103440 (2020).

49 Kiphard, E. J. \& Schilling, F. Koperkoordinationtestfur Kinder. (Beltz Test GmbH, 1974).

50 Laukkanen, A. et al. Comparison of motor competence in children aged 6-9 years across northern, central, and southern European regions. Scand J Med Sci Sports. 30, 349-360;10.1111/sms.13578 (2020).

51 Tchamo, M. E., Moura-Dos-Santos, M. A., Dos Santos, F. K., Prista, A. \& Leandro, C. G. Deficits in anthropometric indices of nutritional status and motor performance among low birth weight children from Maputo City, Mozambique. Am J Hum Biol. 29; 10.1002/ajhb.22949 (2017).

52 Moreira, J. P. A. et al. Körperkoordinationstest Für Kinder (KTK) for Brazilian Children and Adolescents: Factor Analysis, Invariance and Factor Score. Front Psychol. 10; 10.3389/fpsyg.2019.02524 (2019).

53 Schilling, F. Sum of Raw Scores of Each KTK Test. (ed jmaia@fade.up.pt) (2015).

54 Council of Europe. Eurofit: Handbook for the Eurofit Tests of Physical Fitness. (Council of Europe, Committee for the Development of Sport, 1993).

55 AAHPERD. Physical Educations, Recreation and Dance. In Health Related Physical Fitness Manual (Washington, DC, USA, 1980).

56 Huang, Y. C. \& Malina, R. M. BMI and health-related physical fitness in Taiwanese youth 9-18 years. Med Sci Sports Exerc. 39, 701-708;10.1249/mss.0b013e31802f0512 (2007).

57 Pereira, S. et al. Sibling Similarity in Metabolic Syndrome: The Portuguese Sibling Study on Growth, Fitness, Lifestyle and Health. Behav genetics 49, 299-309, doi:10.1007/s10519-019-09953-y (2019).

58 Joint Consortium for School Health. Healthy School Planner. , www.healthyschoolplanner.uwaterloo.ca. (2012).

59 West, B., Welsch, K. \& Galecki, A. Linear mixed models. A practical guide using statistical software. (Chapman \&Hall/CRC, 2007).

\section{Figures}


a)

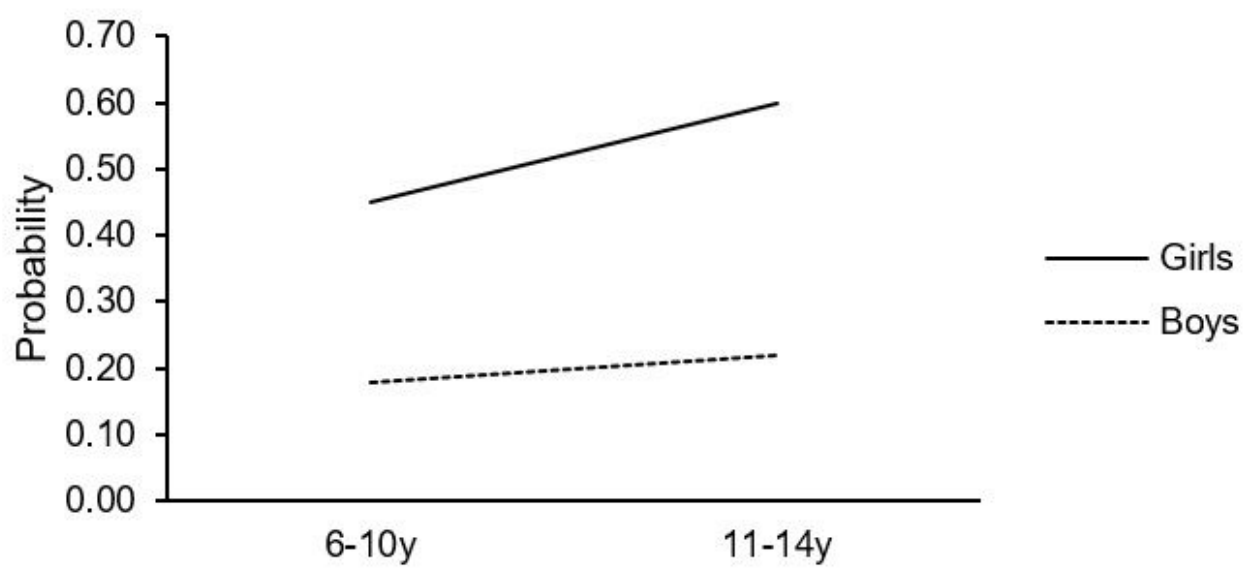

b)

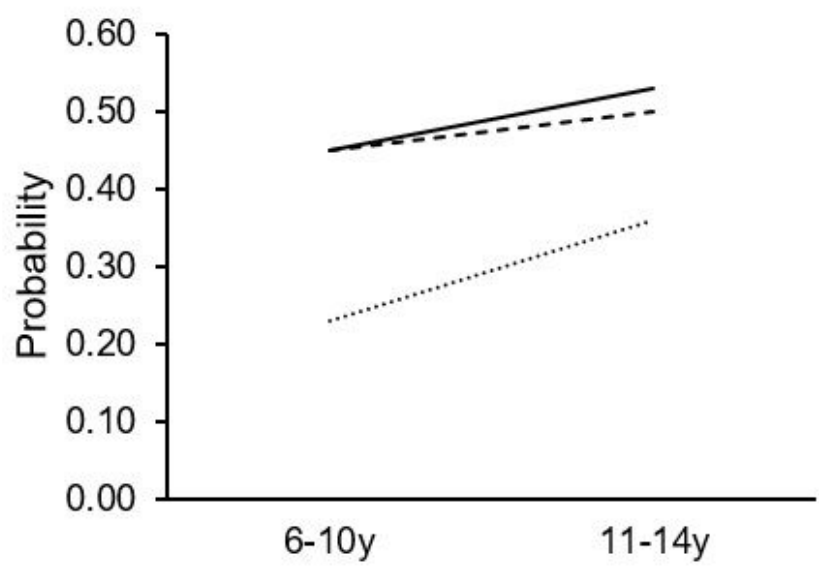

c)
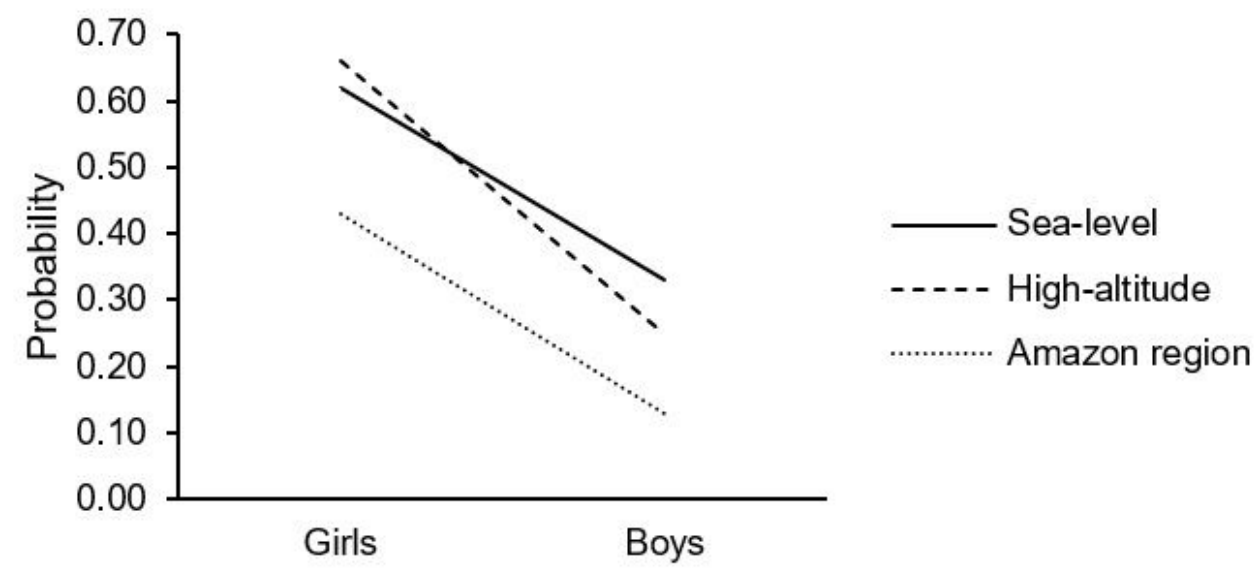

Figure 1

Plots of probabilities of having GMC problems: age-by-sex (a) age-by-geographical location (b) and sexby-geographical location (c) interactions. 


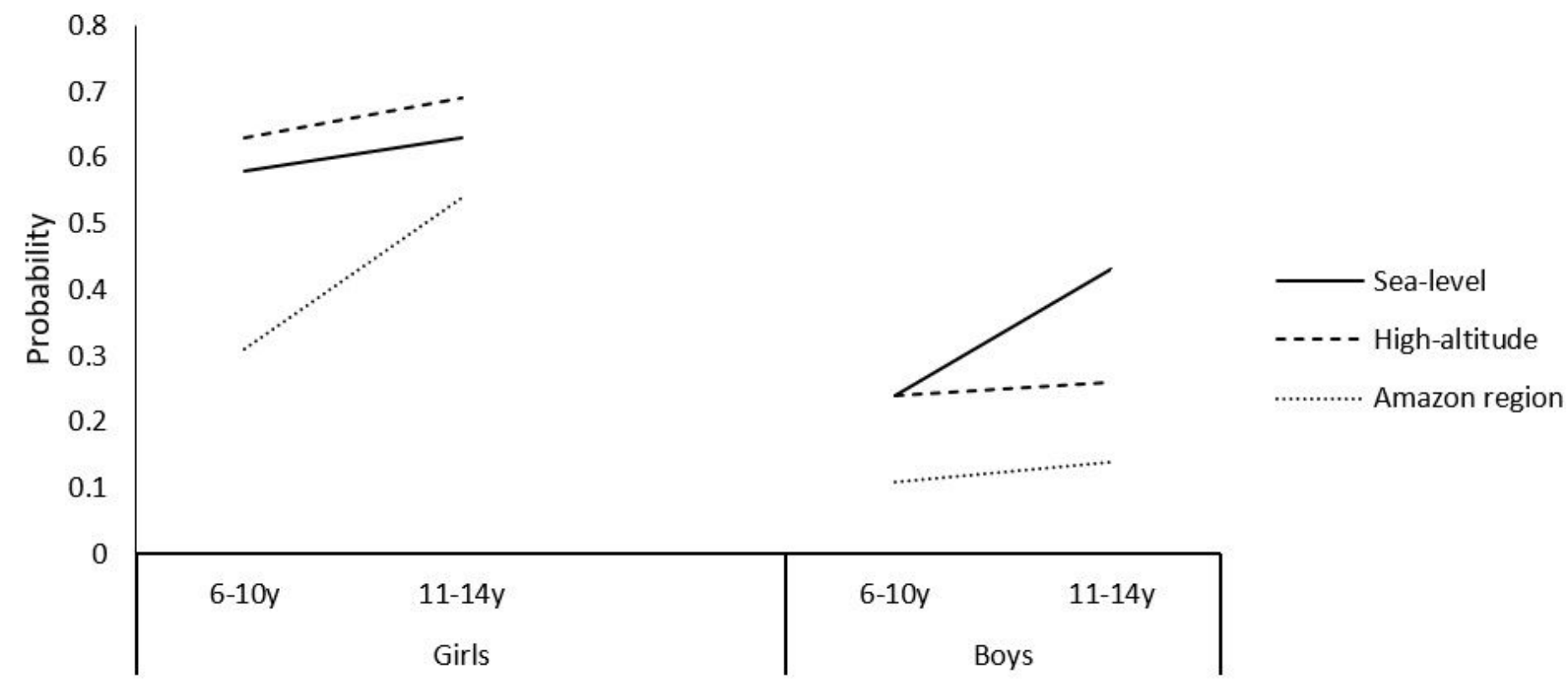

Figure 2

Plots of probabilities of having GMC problems: age-by-sex-by-geographical area interaction 